Dicle Tıp Dergisi / Dicle Med J (2019) 46 (2) : 321 - 325

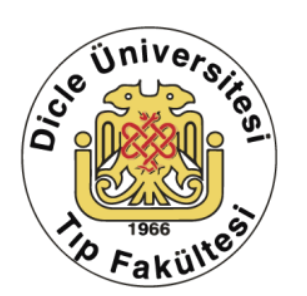

WWW.diclemedj.org

Özgün Araștırma / Original Article

\title{
The Proper use of Inhalers in a Third Step Hospital and its Effect on Treatment: Original Study
}

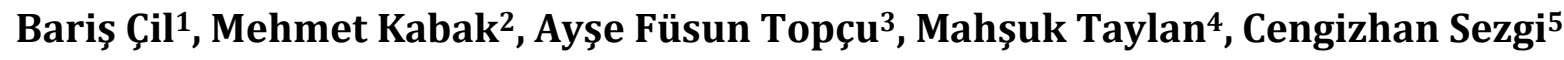 \\ 1 Mardin State Hospital Department of Chest Diseases Mardin, Turkey ORCID: 0000-0003-1090-0697 \\ 2 Dicle University School of Medicine Department of Chest Diseases, Dalı Diyarbakır, Turkey ORCID: 0000-0003-4781-1751 \\ 3 Dicle University School of Medicine Department of Chest Diseases, Dall Diyarbakır, Turkey ORCID: 0000-0001-7570-2339 \\ 4 Dicle University School of Medicine Department of Chest Diseases, Dalı Diyarbakır, Turkey ORCID: 0000-0003-4072-2270 \\ 5 Dicle University School of Medicine Department of Chest Diseases, Dalı Diyarbakır, Turkey ORCID: 0000-0002-5980-3874
}

Received: 25.12.2018; Revised: 20.03.2019; Accepted: 26.03.2019

\begin{abstract}
Objective: The percentage of asthma patients that use their inhalers with the correct technique ranges between 10 and 60. Inappropriate use of inhaler leads to disuse of drug, diminished disease control and increased drug use. In this study, we aimed to determine the effect of proper inhaler therapy on the treatment and control of asthma and the effect of proper inhaler use on hospitalization due to asthma.

Method: One hundred and sixty five asthma patients over 18 years of age that applied to either in- or out-patient clinics of a university hospital, that had a diagnosis of asthma according to the criteria of the Global Initiative for Asthma (GINA) and had been attack-free for at least one month were included. Patients were told to use their inhalers and any misuse were noted. Patients were put through the Asthma Control Test (ACT). Their forced vital capacity (FVC), forced expiratory volume in 1 second (FEV1) and peak expiratory flow (PEF) values were also noted. Their hospitalization status for asthma in the last year was assessed and recorded.

Results: One hundred patients used their asthma inhalers correctly, while 65 did not. Those that used their inhalers correctly had significantly higher ACT ( $p=0,0001)$, FEV1\% $(p=0,001)$ and PEF\% $(p=0,014)$.

Discussion: Patients must be informed and trained for the correct use of their inhaler drugs. Patients seem to be under-informed on this subject and there are serious mistakes of use for all inhaler types. Correct use of inhalers leads to better control of disease, lower rate of asthma-related hospitalization, less drug waste and decreased treatment cost.
\end{abstract}

Keywords: Asthma, treatment, inhaler.

DOI: $10.5798 /$ dicletip

Yazışma Adresi / Correspondence: Bariş̧ Çil, Mardin State Hospital Department of Chest Diseases Mardin, Turkey e-mail: drbariscil@hotmail.com 


\section{Üçüncü basamak bir hastanede doğru inhaler kullanımı ve bunun tedaviye etkisi: Özgün Çalışma}

\section{Öz}

Giriș: Astımlı hastaların doğru teknikle inhaler kullanma oranları \%10-60 arasında değișmektedir. Uygunsuz inhaler tekniği; ilacın kötü kullanımına, azalmış hastalık kontrolüne ve artmış ilaç kullanımına neden olur. Bu çalıșmamızda doğru inhaler kullanımının astımın tedavisine ve kontrolüne etkisini ve doğru inhaler kullanımın hastane yatışı üzerindeki etkisini bulmayı amaçladık.

Yöntemler: Bu çalışmada bir üniversitede Göğüs Hastalıkları Kliniğinde yatarak tedavi gören veya polikliniğine ayaktan başvuran, The Global Initiative for Asthma (GINA)'ya göre astım tanısı almış remisyon döneminde 18 yaş ve üzeri olan 165 hasta değerlendirildi. Hastalara inhalerleri kullandırılarak ilaçlarını doğru mu yanlış mı kullandığı kayıt edildi. Hastaların astım atağından üzerinden en az 1 ay geçmesi ve atak dışı dönemde olması koşuluyla hastalara Astım kontrol testi (AKT) yapıldı. Hastaların solunum fonksiyon testleri yapılıp zorlu vital kapasite(FVC), zorlu ekspiratuvar volüm 1. Saniye (FEV1) ve zirve akım hızı (PEF) değerleri kayıt edildi ve hastaların son 1 yıl içinde astım atak nedeniyle hastaneye yatışları sorgulanıp kaydedildi.

Bulgular: Hastaların doğru ilaç kullanımıyla AKT skoru, FEV1 yüzdesi, PEF yüzdesi, son bir yıl içinde hastaneye yatış sayısı istatistiksel olarak karşılaştırıldı. Hastaların 100'ü astım ilacını doğru kullanıyorken, 65 hasta ilacını yanlış kullanıyordu. İlacını doğru kullanan grupta AKT ( $\mathrm{p}=0.0001)$, FEV1 yüzdesi ( $\mathrm{p}=0.001)$, PEF yüzdesi ( $\mathrm{p}=0.014)$ anlamlı olarak daha yüksek bulundu.

Sonuç: Hastalar inhaler ilaçlar konusunda mutlaka bilgilendirilmeli ve eğitilmelidir. Tüm inhaler ilaç formları için ciddi kullanım hataları mevcut olup hastalar açısından önemli bilgi eksikliği de söz konusudur. Doğru inhaler kullanımıyla beraber hastanın astımı kontrol altına alınıp daha az sayıda ve düşük doz ilaç kullanması, hastane yatışlarının daha az olması sağlanabilir ve böylece astımda maliyet de düşürülebilir.

Anahtar kelimeler: Astım, tedavi, inhaler.

\section{INTRODUCTION}

Asthma is a heterogeneous disease characterized by chronic airway inflammation associated with airway hypersensitivity to direct or indirect stimuli ${ }^{1}$. It manifests with respiratory symptoms and expiratory airflow limitation such as wheezing, shortness of breath, chest tightness and / or cough ${ }^{1}$.

Inhaled medications are the cornerstone of the treatment and management of asthma ${ }^{2}$. Effective asthma management can only be done with good self-management and optimal use of asthma medications via inhaler device ${ }^{3,4}$.

Inhaled treatment has many advantages such as direct fast onset of action due to local delivery, high concentration of the drug in the airways with minimal systematic side effects. However, use of these medications with improper technique leads to the inefficacy of treatment ${ }^{5-8}$. Inefficient inhaler treatment results in poor asthma outcomes, frequent exacerbations, increased hospitalization rates and medication $\cos ^{3,5,8,9}$.

There are many devices for the delivery of inhaled medications, including pressurised metered-dose inhalers (pMDIs), dry-powder inhalers (DPIs), soft-mist inhalers, breathactuated MDIs, and nebulisers $2,10,11$. While the wide array of treatments available may be seen as positive, the large number of available devices can result in a certain amount of complexity for prescribers when teaching patients their correct use.

The ratio of asthma patients that correctly use their inhaler devices ranges between 10 and $60 \% 12$.

In this study, we aimed to determine the effect of proper inhaler therapy on the treatment and 
control of asthma and the effect of proper inhaler use on hospitalization due to asthma

\section{METHODS}

One hundred and sixty five patients over 18 years of age that applied to either in- or outpatient clinics of one University Chest Diseases Department between June 1st 2011 - June 1st 2013, that had a diagnosis of asthma according to the criteria of the Global Initiative for Asthma(GINA) and had been attack-free for at least one month were included. These patients consisted of 38 males and 127 females.

Patients were asked to use their inhaler and any misuse was noted. Patients that were attack-free for at least one month and were so at the time of visit were put through the Asthma Control Test (ACT). Those with ACT $\leq 19$ were considered uncontrolled, those with 20 $\leq \mathrm{ACT} \leq 24$ were partially-controlled and ACT $=25$ cases were noted as fully controlled asthmatics. Because the number of patients in the fully-controlled asthma group was low, these were merged into a single group with partially-controlled patients.

Respiratory function tests were carried out to get forced vital capacity (FVC), forced expiratory volume in 1 second (FEV1) and Peak Expiratory Flow (PEF) values. Their hospitalization status for asthma in the last year was assessed and recorded.

\section{Statistical Analysis}

Means were used to note descriptive statistics of continuous variables. Categorical variables were described in cross tables and their associations were analyzed using the chisquare test with Yates correction. Means were analysed using Student's t test.

All hypotheses were two-sided, values of $\mathrm{p} \leq 0.05$ were deemed statistically significant. Statistical analyses were carried out using the
SPSS 15.0 for Windows (SPSS Inc., Chicago, IL, USA).

\section{RESULTS}

A total of 165 patients were enrolled in the study. The mean age of patients was $39.6 \pm 13.9$ years, $101(61.2 \%)$ of the patients were smokers and $76.9 \%$ of them were females. One hundred patients used their asthma inhalers correctly, while $65(39.4 \%)$ did not. Those that used their inhalers correctly had lower numbers of asthma-related hospitalization in the last year, but this was not statistically significant $(p=0,06)$. The association between proper inhalers technique with their ACT scores, FEV1 and PEF percentages was assessed statistically; older patients tended to have a higher risk of improper inhaler use $(\mathrm{p}=0.043)$. (Table 1, Table 2).

Table1: The association of proper use of inhaler drugs and pertinent clinical parameters in asthma patients

\begin{tabular}{|l|l|l|l|}
\hline & $\begin{array}{l}\text { Correct use } \\
\mathrm{n}: 100\end{array}$ & $\begin{array}{l}\text { Incorrect use } \\
\mathrm{n}: 65\end{array}$ & $\mathrm{P}$ \\
\hline $\begin{array}{l}\text { Gender } \\
\text { (female/male, number) }\end{array}$ & $77 / 23$ & $50 / 15$ & $\mathrm{NS}$ \\
\hline Age (year) & $37.83 \pm 13.64$ & $42.32 \pm 14.10$ & $\mathrm{P}: 0.043$ \\
\hline ACT & $19.47 \pm 4.20$ & $15.52 \pm 3.99$ & $\mathrm{P}: 0.0001$ \\
\hline PEF \% & $84.13 \pm 19.62$ & $75.84 \pm 22.82$ & $\mathrm{P}: 0.014$ \\
\hline FEV1\% & $89.01 \pm 17.70$ & $79.04 \pm 20.94$ & $\mathrm{P}: 0.001$ \\
\hline $\begin{array}{l}\text { Hospitalizations in the } \\
\text { last year because of } \\
\text { asthma(number, } \\
\text { percent) }\end{array}$ & $12(12 \%)$ & $25(23.1 \%)$ & $\mathrm{P}: 0.06$ \\
\hline \begin{tabular}{l} 
P<0,05 are statistically significant, NS:statically not significant \\
\hline
\end{tabular}
\end{tabular}

Table 2: The relationship between correct/incorrect use of the drug and ACT

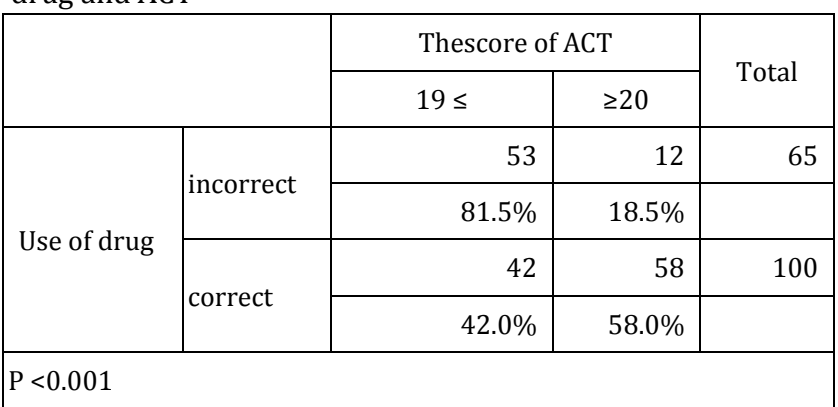




\section{DISCUSSION}

In a study by the World Health Organization (WHO), it was reported that the rates of mismatch in patients undergoing long-term drug treatment were $50 \%$ or higher ${ }^{13}$. Asthmatic patients who have to undergo longterm treatment due to chronic respiratory diseases are also at risk for treatment incompatibility.

The long-term goals of asthma management are to control symptoms and to reduce the risk of exacerbations. Inhaled medication is the cornerstone of pharmacological treatment for asthma; therefore, good inhalation technique is the key for asthma management. However, up to $70 \%$ of asthma patients do not use their inhalers correctly. There is evidence on how poor inhalation techniques associated to poor asthma control ${ }^{14}$.

Inhalation devices that form the mainstays of asthma treatment are the main factors that increase therapy cost and sufficient amounts of drug need to reach to the bronchial mucosa to be efficient. This can only be possible by teaching patients using techniques. When the multitude of inhaler devices in market is considered, describing the correct use of these devices to patients brings excessive workload to physicians. The resulting lack of training, combined with patient's cognitive or physical disabilities, not picking the right device for the specific patient, sociocultural and educational differences commonly lead to lack of conformity to inhaler treatment, inability to use or misuse of the inhaler device ${ }^{15-20}$.

Patients using inhaler devices make several mistakes in various steps. These mistakes cause little or no drug access; leading to insufficient treatment and loss of disease control ${ }^{21-26}$.

Efficacy of inhaler treatment depends on correct administration. It is reported that written material alone is insufficient and verbal communication and demonstration of devices are required ${ }^{12}$. In a study by Aydemir, the rate of correct inhaler users increased from 55.3\% to $83.7 \%$ after inhaler technique training. They reported an increase from $58.9 \%$ to 92.6 for measured dose inhalers, from $31.1 \%$ to $45.2 \%$ in dry dose inhalers ${ }^{27}$. Three months after a training session, the trial group maintained a higher rate of high ACT scores ACT $>19$ (43\% vs $77 \%)(p<0.001)$ whereas the control group remained stable (57\% to $67 \%, \mathrm{p}>0.1)^{28}$.

Variable results have been reported with regards to the association of age and improper use of inhaler devices. There are studies that claim older age decreases the rate of correct inhaler use, and those that show no such association $^{29,30}$. In our study, the mean age of the patients that use their devices incorrectly was higher than those that use them correctly. We think that this data implies older patients require more careful and frequent training on device use.

The present study demonstrates the importance of patient education and guidance for the use of inhaler devices. There are significant mistakes at administration of all these devices and patients lack proper information. Proper use of inhaler devices will help control asthma with lower number of devices and lower doses, less need for hospitalization and therefore reduce healthcare expenditure in the asthmatic population.

Conflicts of interest: The authors have no conflict of interests to declare.

Financial Disclosure: The authors declared that this study has received no financial support

\section{REFERENCES}

1. Global Initiative for Asthma(GINA). Global strategy for asthma management and prevention(Update2018).http://ginasthma.org/2018gina-report-global-strategy-for-asthma-managementand-prevention/ . Accessed 15 January 2018.

2. Global Initiative for Asthma (GINA). 2017 GINA Report, Global Strategy for Asthma Management and 
Prevention. http://ginasthma.org/2017-gina-reportglobal-strategy-for-asthma-management-andprevention/. Accessed 13 December 2017.

3. Vasbinder EC, Janssens HM, Rutten-van Mölken MP, et all. e-Monitoring of Asthma therapy to improve compliance in children using a real-time medication monitoring system (RTMM): the e-MATIC study protocol. BMC Med Inform Decis Mak. 2013; 13: 38.

4. Bosnic-Anticevich SZ, Stuart M, Mackson J, et all. Development and evaluation of an innovative model of inter-professional education focused on asthma medication use. BMC Med Educ. 2014; 14: 72.

5. Melani AS, Bonavia $\mathrm{M}$, Cilenti $\mathrm{V}$, et all. Inhaler mishandling remains common in real life and is associated with reduced disease control. Respir Med. 2011; 105: 930-8.

6. Pedersen S, Dubus JC, Crompton GK; ADMIT Working Group. The ADMIT series--issues in inhalation therapy. Inhaler selection in children with asthma. Prim Care Respir J. 2010; 19: 209-26.

7. Price D, Bosnic-Anticevich S, Briggs A, et all. Inhaler competence in asthma: common errors, barriers to use and recommended solutions.Respir Med. 2013; 107: 37-46.

8. Al-Jahdali $\mathrm{H}$, Ahmed A, Al-Harbi A, et all. Improper inhaler technique is associated with poor asthma control and frequent emergency department visits. Allergy Asthma Clin Immunol. 2013; 9: 8.

9. Crompton GK, Barnes PJ, Broeders M, et all. Aerosol Drug Management Improvement Team. The need to improve inhalation technique in Europe: a report from the Aerosol Drug Management Improvement Team. Respir Med. 2006; 100: 1479-94.

10. Global Strategy for the Diagnosis, Management, and Prevention of Chronic Obstructive Pulmonary Disease. http://goldcopd.org/wpcontent/uploads/2017/11/GOLD-2018-v6.0-FINALrevised-20-Nov_WMS.pdf. Accessed 13 December 2017.

11. Laube BL, Janssens HM, de Jongh, et all. What the pulmonary specialist should know about the new inhalation therapies. Eur Respir J. 2011; 37: 1308-31.

12. Cochrane MG, Bala MV, Downs KE, et all. Inhaled corticosteroids for asthma therapy. Patient compliance, devices, and inhalation technique. Chest. 2000; 117: 542-50.

13. Adherence to long-term therapies. Evidence for action. Geneva: World Health Organization (2003). https://www.who.int/chp/knowledge/publications/ad herence_report/en/. Accessed 13 December 2017.

14. Román-Rodríguez M, Metting E, Gacía-Pardo M, et all. Wrong inhalation technique is associated to poor asthma clinical outcomes. Is there room for improvement?.Curr Opin Pulm Med. 2019; 25: 18-26.

15. Erk M. İnhalasyon teknikleri. Toraks Dergisi. 2002; 3: 7-13.
16. Rau JL. Practical problems with aerosol therapy in COPD. Respir Care, 2006; 51: 158-72.

17. Fink JB, Rubin BK. Problems with inhaler use: a call for improved clinician and patient education. Respir Care. 2005; 50: 1360-74.

18. King D, Earnshaw SM, Delaney JC. Pressurised aerosol inhalers: the cost of misuse. Br J Clin Pract. 1991; 45: 48-9.

19. Lavorini F, Magnan A, Dubus JC, et all. Effect of incorrect use of dry powder inhalers on management of patients with asthma and COPD. Respir Med. 2008; 102: 593-604.

20. Chapman KR, Voshaar TH, Virchow JC. Inhaler choice in primary practice. Eur Respir Rev. 2005; 96: 117-22.

21. Plaza, V, Sanchis, J. Medical personnel and patient skill in the use of metered dose inhalers: a multicentric study. CESEA Group, Respiration. 1998; 65: 195-8.

22. Shrestha, M, Parupia H, Andrews B,et al. Metereddose inhaler technique of patients in an urban ED: prevalence of incorrect technique and attempt at education. Am J Emerg Med.1996; 14: 380-4.

23. Brocklebank D, Ram F, Wright J, et all. Comparison of the effectiveness of inhaler devices in asthma and chronic obstructive airways disease: a systematic review of the literature, Health Technol Assess. 2001; 5: $1-149$.

24. Giraud V, Roche N. Misuse of corticosteroid metereddose inhaler is associated with decreased asthma stability. Eur Respir J. 2002; 19: 246-51.

25. Van der Palen J, Klein JJ, Kerkhoff AH, et all. Evaluation of the effectiveness of four different inhalers in patients with chronic obstructive pulmonary disease. Thorax.1995; 50: 1183-87.

26. Everard ML, Role of inhaler competence and contrivance in "difficult asthma", Paediatr Respir Rev.2003; 4: 135-42.

27. Aydemir Y. Assessment of the factors affecting the failure to use inhaler devices before and after training. Respir Med. 2015; 109: 451-8.

28. Schuermans D, Hanon S, Wauters I, et all. Impact of a single 10 min education session on asthma control as measured by ACT.Respir Med.2018; 143: 14-17.

29. Rootmensen GN, van Keimpema AR, Jansen HM, et all. Predictors of incorrect inhalation technique in patients with asthma or COPD: a study using a validated videotaped scoring method. J Aerosol Med Pulm Drug Deliv 2010; 23: 323-8.

30. Goodman DE, Israel E, Rosenberg $M$, et all. The influence of age, diagnosis, and gender on proper use of metered-dose inhalers. Am J Respir Crit Care Med 1994; 150: 1256-61. 